\title{
Skier's thumb injury -- Whistler experience
}

\author{
Kimit Rai MB FRCSC \\ New Westminster, British Columbia
}

K Rai. Skier's thumb injury -- Whistler experience. Can J Plast Surg 1995;3(4):203204. Thirty-eight per cent of skiing injuries seen at the Health Care Centre in Whistler, British Columbia are related to thumb injuries. A diagnosis of skier's thumb injury is made by clinical evaluation. The confirming diagnostic procedure is a positive stress test of the thumb, supported by supplementary investigations such as radiography, which may show an avulsion chip fracture with a localized area of tenderness. The treatment plan involves surgical exploration and ligament repair for total tear of the ulnar collateral ligament. Patients do extremely well with reconstruction and are able to return to skiing after six weeks, and to work between four to six weeks post surgery. Patients who refuse surgery do not do so well and have unstable painful thumbs with a weak pinch, and are likely to require future reconstructive surgery. Partial tears with a positive stress test have better results with surgical intervention and reconstruction of the ligament, rather than splinting alone. Finally, partial tears with a negative abduction stress test do well with splinting alone for six weeks.

Key Words: Skier's thumb, Ulnar collateral ligament

\section{$<<$ Pouce du skieur $>>$, expérience de Whistler}

RÉSUMÉ : Trente-huit pour cent des blessures liées au ski observées au Centre de santé de Whistler, en Colombie- Britannique, ont à voir avec des blessures au pouce. Le diagnostic de pouce du skieur se base sur une évaluation clinique. Ce diagnostic est confirmé en présence de tests positifs appuyés par des examens complémentaires comme la radiographie qui peut révéler une avulsion, une fêlure avec zone de sensibilité localisée. Le plan de traitement met en jeu l'exploration chirurgicale, une réparation ligamentaire lors d'un déchirement total du ligament collatéral cubital. Les patients évoluent très bien lors d'une reconstruction et peuvent retourner skier après six semaines et reprendre le travail quatre à six semaines après l'intervention. Les patients qui refusent la chirurgie n'évoluent pas si bien : leurs pouces sont douloureux et instables, avec de faibles pincements et les patients risquent de nécessiter une chirurgie de reconstruction plus tard. Les déchirures partielles avec tests positifs donnent de meilleurs résultats lors de l'intervention chirurgicale et de la reconstruction du ligament plutôt que lors de l'emploi d'une attelle seulement. Finalement, les déchirures partielles avec résultats négatifs aux tests d'abduction récupèrent bien avec l'utilisation d'une attelle seule pendant six semaines. 
The ski resort at Whistler, British Columbia is one of the most popular locations in North America for skiers, attracting approximately 1.3 million people every year. Of the various injuries that can occur among skiers, thumb injuries are among the most common.

The mechanism of injury is one where the thumb undergoes an abduction at the metacarpophalangeal (MCP) joint, caused either by a ski pole, collision, falling on an icy mountain, or direct impact on the thumb, while the skier is falling. Diagnosis is made by: assessment of the mechanism of injury; a clinical examination of the patient, confirmed by localized tenderness at the MCP joint; a positive abduction stress test of the thumb; and radiography to assess the MCP joint, where there could be a fracture (though the radiographs may be normal).

The indications for surgery are: a positive stress test; a radial abduction deformity; and radiographs showing displacement chip fracture of the MCP joint.

The pathophysiology is of a tear of the ulnar collateral ligament of the thumb, where the torn ligament shrinks volarwards, and moves proximally. If untreated, the ligament becomes a ball, with scar tissue on the volar side of the MCP joint, restraining the MCP joint and keeping it in flexion. This produces a thumb that is fairly swollen and tender, extremely unstable at the MCP joint, with a poor pinch and a poor grip. The resulting deformity is disabling, with limited function of the thumb.

\section{TREATMENT}

Treatment involves surgical repair of the ulnar collateral ligament with a pull-out wire suture passed across the ulnar side towards the radial side of the MCP joint, to secure the ligament, and a K-wire fixation to immobilize the joint for three weeks. Following that, the $\mathrm{K}$-wire is removed and the patient is placed in a radial support splint which is worn for another three weeks before returning to full activity. If the tear of the ligament is minimal, and the forced abduction test is negative, the patient can be treated by splinting alone for six weeks, immobilizing the interphalangeal joint and the MCP joint, as well as the wrist joint. If the tear of the ulnar collateral ligament is partial, and the forced abduction test of the thumb is positive, the patient is also treated by surgical repair of the ligament and K-wire fixation and splinting for three weeks, after which the $\mathrm{K}$-wire is removed and the patient is splinted for another three weeks. If these latter patients are treated conservatively with a splint which immobilizes the interphalangeal, MCP and wrist joints, results are limited. They have swollen thumbs with tenderness, limited function of the thumb, laxity and instability at the MCP joint. Therefore, the surgical decision is dependent on the assessment of the forced abduction test of the MCP joint of the thumb.

The test can be easily performed by injecting local anaesthetic in the area during the evaluation. If the test is positive, these patients do well with surgical intervention and reconstruction, and a six week period of immobilization, with very little residual disability. If the forced abduction test at the MCP joint is negative, these patients can be treated by using the splinting program alone for six weeks, without surgical intervention, with very acceptable results and a good functional thumb. 


\section{SURGICAL TECHNIQUE AND RESULTS}

A dorso-ulnar incision is made (Figure 1) and the extensor expansion is exposed. On the ulnar side, the abductor aponeurosis and extensor expansion is opened (Figure 2). The dorsal branch of the digital nerve is retracted laterally. The torn ligament is exposed, and a drill hole is made on the ulnar side of the proximal phalanx. Ligament repair is done with a 4.0 Bunnell pull-out wire suture (Figure 3). The extensor expansion is repaired, and a $35 \mathrm{~K}$-wire is used, immobilizing the MCP joint of the thumb. Two doses of intravenous antibiotics are given.

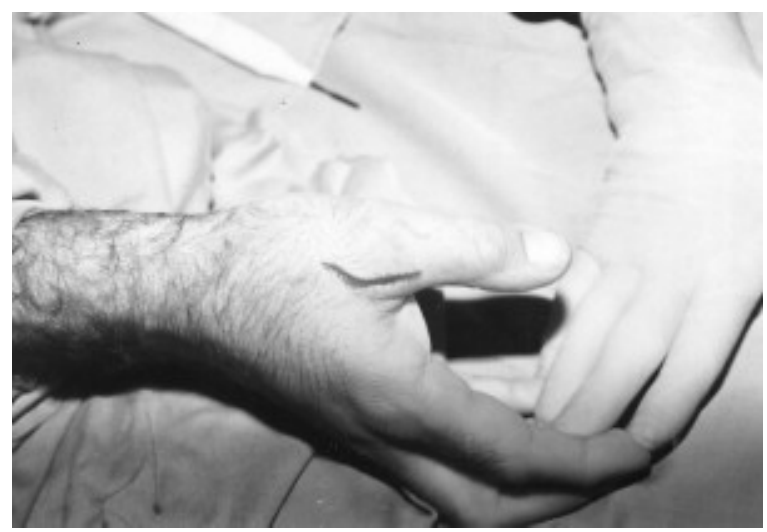

Figure 1) Position of dorso-ulnar incision

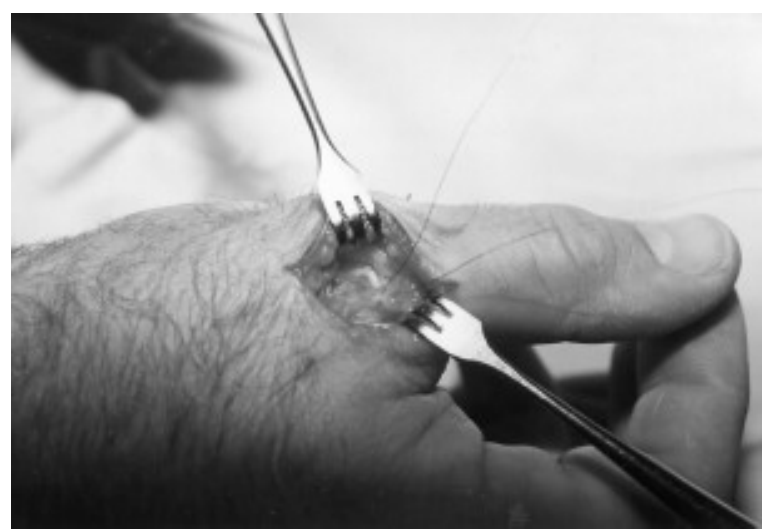

Figure 3) Ligament ready for pull-through - drill hole site

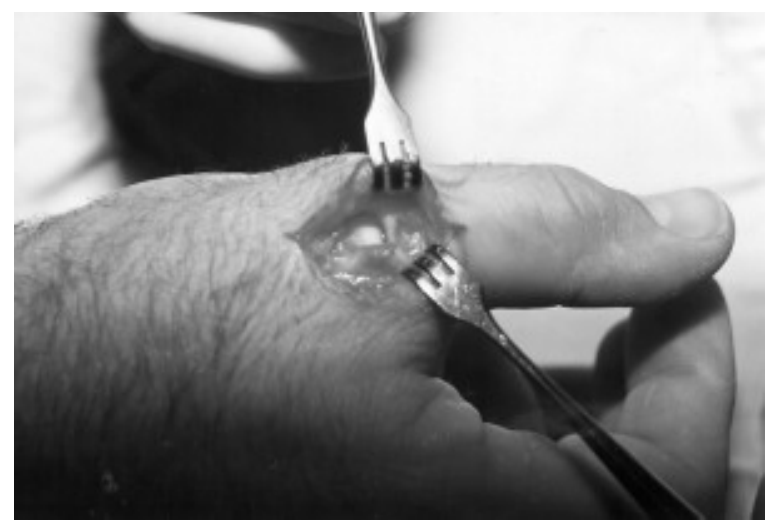

Figure 2) Ulnar proximal phalanx preoperative -- torn ligament insertion

TABLE 1: Results from 45 cases of thumb injuries resulting from skiing accidents during the 1992-93 skiing season

\begin{tabular}{|l|l||l|l|l||}
\hline Total cases & Total tears & Partial tears & Partial tears \\
\hline \hline & $\begin{array}{l}\text { Positive stress } \\
\text { test }\end{array}$ & Negative stress test & Negative stress test \\
\hline \hline & Surgical repairs & $\begin{array}{l}\text { Surgical } \\
\text { repairs }\end{array}$ & Refused surgery & $\begin{array}{l}\text { No surgery, Splinting six } \\
\text { weeks }\end{array}$ \\
\hline \hline 45 & 20 & 10 & 6 & 9 \\
\hline \hline Complications & None & None & $\begin{array}{l}\text { Swollen, Weak pinch, } \\
\text { Pain }\end{array}$ & None \\
\hline
\end{tabular}


The results from 45 cases operated on during the 1992-93 ski season are presented in Table 1.

\section{DISCUSSION}

Ligamentous injury of the thumb should be assessed properly. The stress test is important in establishing the diagnosis. Patients with partial tears are often treated conservatively, but show poor results when the stress test is positive. If there is a doubt over the diagnosis, it is better to treat the patient using surgical exploration and diagnostic assessment and management, rather than conservative splint treatment. Surgery produces excellent results with a small scar. A misdiagnosis can lead to a painful, unstable, swollen thumb, with significant compromise of function, and weak pinch and grip. When in doubt, it is better to explore and treat, rather than guess and splint, and achieve questionable results. 